\title{
Non-Invasive Fetal Electrocardiogram Monitoring Techniques: Potential and Future Research Opportunities in Smart Textiles
}

\author{
Geetika Aggarwal *(D) and Yang Wei $(\mathbb{D}$ \\ Smart Wearable Research Group, Department of Engineering, Nottingham Trent University, \\ Nottingham NG11 8NS, UK; yang.wei@ntu.ac.uk \\ * Correspondence: geetika.aggarwal@ntu.ac.uk
}

Citation: Aggarwal, G.; Wei, Y.

Non-Invasive Fetal

Electrocardiogram Monitoring

Techniques: Potential and Future Research Opportunities in Smart Textiles. Signals 2021, 2, 392-412. https://doi.org/10.3390/signals2030025

Academic Editor: Yoshiharu Yamamoto

Received: 21 February 2021

Accepted: 23 June 2021

Published: 29 June 2021

Publisher's Note: MDPI stays neutral with regard to jurisdictional claims in published maps and institutional affiliations.

Copyright: (c) 2021 by the authors. Licensee MDPI, Basel, Switzerland. This article is an open access article distributed under the terms and conditions of the Creative Commons Attribution (CC BY) license (https:// creativecommons.org/licenses/by/ $4.0 /)$.

\begin{abstract}
During the pregnancy, fetal electrocardiogram (FECG) is deployed to analyze fetal heart rate (FHR) of the fetus to indicate the growth and health of the fetus to determine any abnormalities and prevent diseases. The fetal electrocardiogram monitoring can be carried out either invasively by placing the electrodes on the scalp of the fetus, involving the skin penetration and the risk of infection, or non-invasively by recording the fetal heart rate signal from the mother's abdomen through a placement of electrodes deploying portable, wearable devices. Non-invasive fetal electrocardiogram (NIFECG) is an evolving technology in fetal surveillance because of the comfort to the pregnant women and being achieved remotely, specifically in the unprecedented circumstances such as pandemic or COVID-19. Textiles have been at the heart of human technological progress for thousands of years, with textile developments closely tied to key inventions that have shaped societies. The relatively recent invention of smart textiles is set to push boundaries again and has already opened the potential for garments relevant to medicine, and health monitoring. This paper aims to discuss the different technologies and methods used in non-invasive fetal electrocardiogram (NIFECG) monitoring as well as the potential and future research directions of NIFECG in the smart textiles area.
\end{abstract}

Keywords: non-invasive FECG; fetal monitoring; healthcare

\section{Introduction}

Electrocardiogram (ECG) can be defined as a graphical representation of bioelectrical signals helpful in determining the functionality of the heart through the analysis of graphic representation obtained during the measurement of cardiac cycle of the person or human body. The aim of the biomedical research is to continuously improve the diagnostic devices and develop non-invasive methods of health monitoring, in addition to upgrading already existing devices, thus reducing the cost involved [1-6]. The ongoing research predicts that the main cause of prenatal death is heart defects, as congenital heart defects easily occur during the formation of the heart at the initial stage of pregnancy [7-10].

During the pregnancy, the monitoring of fetal heart rate is essential to identify the proper supply of oxygen, nutrients, and growth of the fetus. Monitoring of the fetus during pregnancy may help in recognizing the pathological conditions, such as fetal hypoxia, allowing prompt medical interventions before irreversible changes taking place. The abnormality in the fetal heart rate of the fetus indicates that there is insufficient oxygen supplied or other problems to the fetus.

FHR during pregnancy or labor can be monitored through invasive and non-invasive fetal methods [11,12] so that the heart functionality of the fetus can be predicted to reflect the growth and wellbeing of the fetus [13-15]. Electrocardiography (ECG) was used by researchers in 1906 to invasively determine the FHR through abdominal during the pregnancy $[15,16]$. In 1958, Edward H. Hon used the successive R waves method from ECG for the calculation and estimation of FHR non-invasively [17-22]. With the advancement in 
technology, Callagan in 1964 monitored the FHR non-invasively using the doppler sound monitoring procedure, in which an ultrasound beam was sent through the abdomen of the mother and the reflected signal was measured, thus helping to analyze FHR [23-27].

Unlike invasive fetal electrocardiography (FECG), which involves surgery to insert the electrodes into the scalp of the fetus through the abdomen of pregnant women, noninvasive fetal electrocardiography (NIFECG) deploys electrodes placed on the abdomen of the pregnant mother to extract the fetus' health information. The electrical signal of the fetal heart rate helps identify the development of the fetus in addition to the presence of any congenital heart disease within the fetus [28-31].

This paper is divided into five sections. Section 2 provides an overview of fetal electrocardiography (FECG). The different techniques to obtain FECG non-invasively are presented in Section 3, where they are critically discussed and compared. The importance of FECG and the electrode configurations for FECG signal extraction are listed in Section 4. Section 5 lists the conclusions, and presents the potential future research directions.

\section{Background of FECG}

Fetal electrocardiogram (FECG) is a biomedical signal, see the example shown in Figure 1, that provides an electrical representation of fetal heart rate (FHR). It is composed of three parts: (i) the P-wave, (ii) the QRS-complex, which is associated with the contraction of the ventricles, and due to the magnitude of the R-wave it is extremely reliable, and (iii) the T-wave, which corresponds to the repolarization phase and follows each heart contraction [31-36]. The delay associated to the R-R interval leads to the heartbeat's frequency and provides useful information about the heart condition. Morphologies of interest include the shape, size, and duration of individual and groups of FECG waveforms as well as the various ratios relating these quantities to each other [19,37-45].

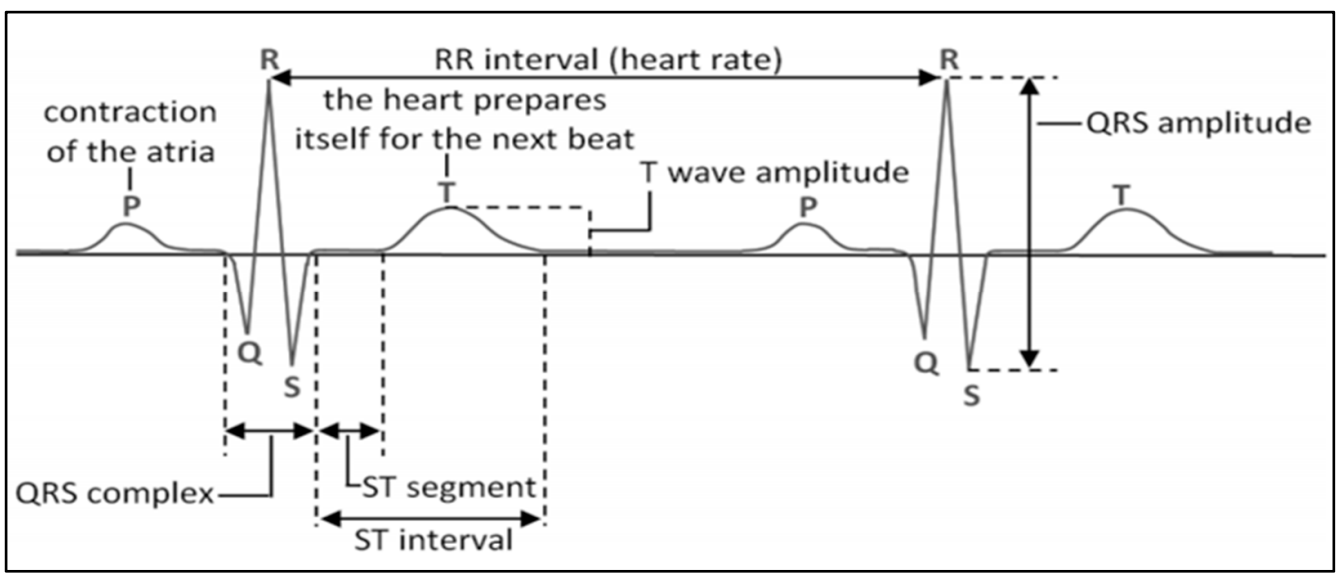

Figure 1. Key features of FECG [45] (Reprinted with permission from ref [45] Radek Martinek (2012)).

The FECG extracted from the maternal electrocardiogram (MECG) is exceedingly small, about 5 times less in amplitude compared to the MECG and is sometimes embedded in the noise signals $[19,42-46]$.

As shown in Figure 2, the FECG signals are usually buried in noise and artefacts, such as interference noise, muscle contractions, instrumental noise, etc., which easily corrupt the FECG signal [47-49]. Therefore, signal processing is essential to remove the noise and artefacts to extract the actual FECG signal to analyze and determine the growth of the fetus [50]. 


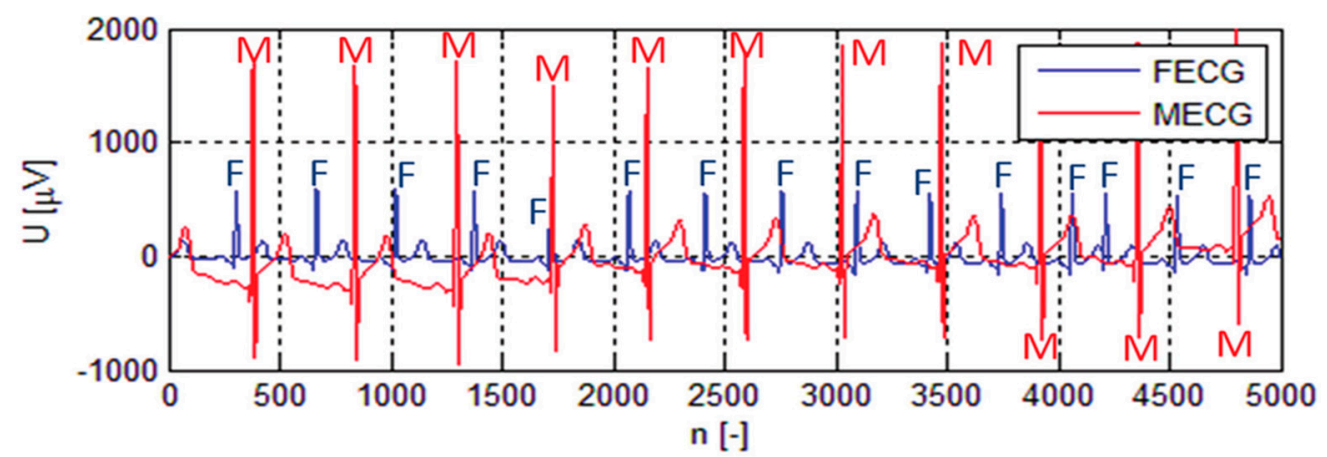

Figure 2. The example of FECG embedded within the MECG signal [45] (Reprinted with permission from ref [45] Radek Martinek (2012)).

\section{Comparison of Fetal Heart Rate Monitoring Techniques}

The fetal heart rate or fetal electrocardiography monitoring thorough abdominal FECG electrodes, i.e., through non-invasive fetal electrocardiogram (NIFECG), has widespread clinical acceptance as it is suitable for long-term recordings without any surgery, unlike invasive FECG. This section illustrates the commonly used fetal heart rate monitoring techniques.

This section illustrates the commonly used non-invasive fetal heart rate monitoring techniques in addition to FECG.

\subsection{Photoplethysmography (PPG)}

Photoplethysmography (PPG) is used to measure the fetal heart rate, introduced in 1930. PPG is a non-invasive fetal monitoring procedure which uses changes in blood level volumes to measure FHR [51-54]. The procedure involves the detection of FHR by transmitting a wavelength of 650-950 $\mathrm{nm}$ through the maternal abdomen, having a peak wavelength of $890 \mathrm{~nm}$ to penetrate the human tissue. The reflected light is analyzed to calculate the fetal heart rate. The example of a PPG signal comprising of both AC and DC components is shown in Figure 3 [53].

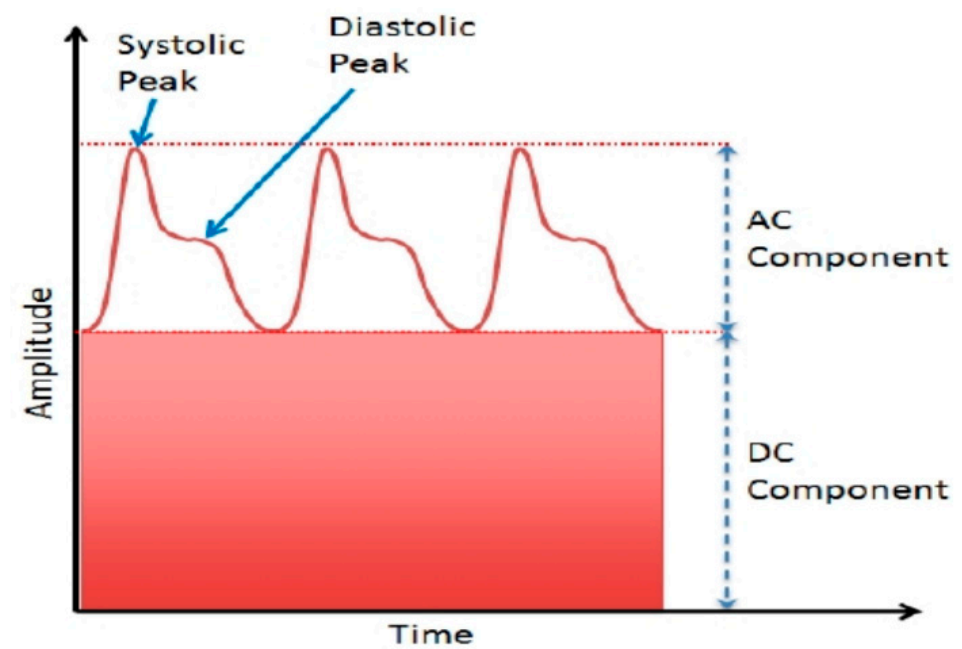

Figure 3. PPG signal comprising of AC and DC components [53] (Reprinted with permission from ref [53] Javier Pérez Contonente).

The AC component is the resultant of pulsatile changes in arterial blood volume, whereas the DC component corresponds to the tissues and muscles [53-55]. The AC component is helpful in determining the FHR as the arterial blood volume is synchronous with the heartbeat, but the signal obtained from the AC component is exceedingly small in range due to noises and artefacts [56,57]. The major challenge in determining fetal heart rate through PPG is the extraction of signals from noisy transducer data, which is mainly 
affected by acoustics, fetal and maternal contractions, fetal movements, and maternal breathing. The authors of [52] introduced a PPG system for fetal heart rate monitoring involving a bandpass filter (BFP) in the range of 710-740 $\mathrm{Hz}$ from the abdomen of the mother, a cut-off frequency of the reference signal kept at $15 \mathrm{~Hz}$, and the signal is downsampled to $55 \mathrm{~Hz}$, followed by a bandpass filter of $0.6-15 \mathrm{~Hz}$ to remove artifacts and unwanted noise in the received signal, deploying four phonogram sensors, as shown in Figure 4a, and the PPG sensors for experiment validation, shown in Figure 4b [52].

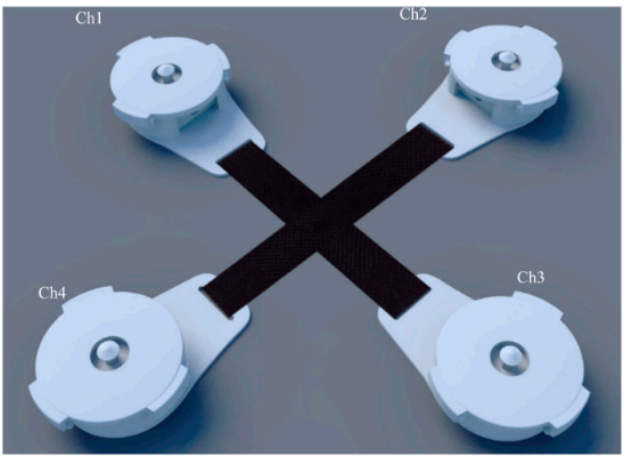

(a)

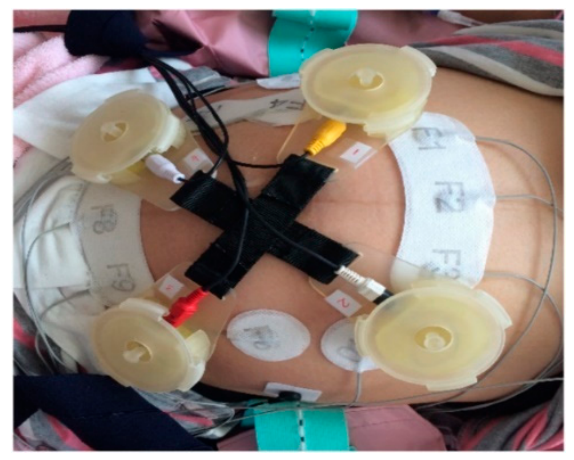

(b)

Figure 4. (a) A schematic diagram showing the locations of phonogram sensors. Ch1, Ch2, Ch3, and Ch4 are four phonogram sensors. (b) Locations of phonocardiogram sensors and fetal ECG electrodes for the cross-validation experiment [52] (Reprinted with permission from ref. [52] (2018, CC BY 4.0)).

The FECG signals were captured invasively using PPG electrodes, and the experiment procedure and signal processing successfully removed the noise and maternal artefacts from the FECG signal $[52,58]$.

\subsection{Cardiotocography (CTG)}

Cardiotocography (CTG) is a procedure for fetal heart rate detection introduced by Konrad Hammacher in 1970 [59-62]. CTG can be carried out both invasively and noninvasively, as shown in Figure 5a [49] and Figure 5b [49]. In invasive CTG, an electrode is directly attached to the scalp of the fetus using a wire through the cervix. In contrast, in non-invasive CTG, electrodes are placed on the abdomen of pregnant women for the fetal heart rate detection. The signal quality of invasive CTG is more accurate but with less comfort and higher risk compared to non-invasive CTG [49,62].

Several studies concluded that long-term continuous monitoring using CTG resulted in discomfort to the patients. In addition, a study comprised of pregnant women at 20 weeks of pregnancy showed that the continuous fetal monitoring using CTG could result in an increase in the number of caesarean sections and misidentification of maternal heart rate $[61,62]$. 


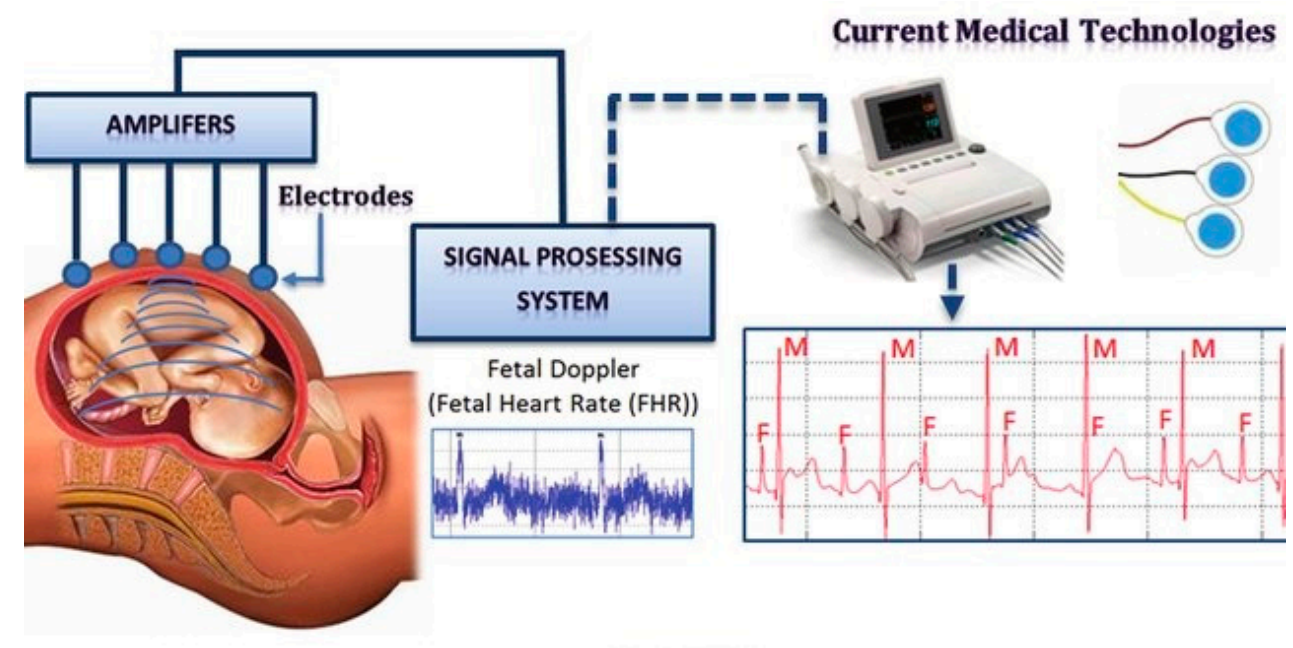

(a)

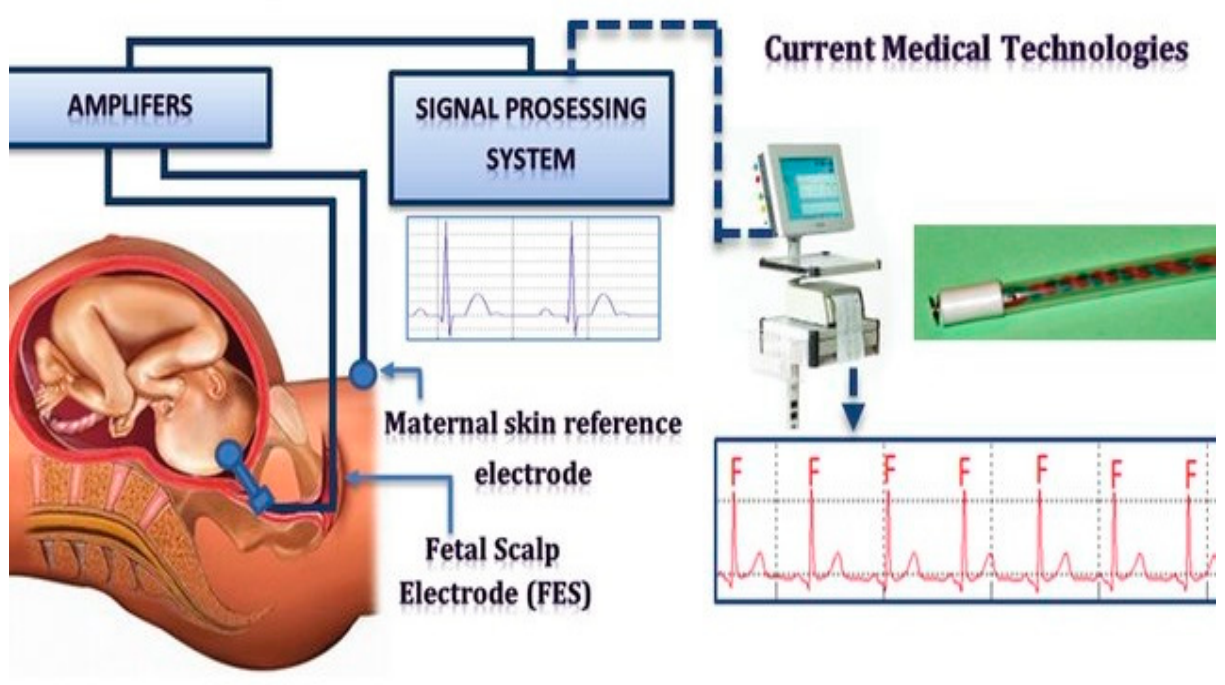

(b)

Figure 5. (a) Non-invasive FECG measurement. (b) Invasive FECG measurement [45] (Reprinted with permission from Radek Martinek (2012)).

\subsection{Doppler Sound}

The Doppler principle is used in fetal heart rate monitoring by analyzing the mechanical activity of the heart, such as movement of valves of the heart of the fetus in the cardiac cycle $[63,64]$. The use of Doppler ultrasound to monitor the FHR, as shown in Figure 6 [64], was proposed in the 1960s, but it is not suitable for continuous monitoring due to discomfort and irritation caused to the patients due to the gel and conduction paste used during the procedure.

The procedure is non-invasive and deploys the ultrasound transducer placed on the maternal abdomen. The ultrasound with the frequency range of $1-2.3 \mathrm{MHz}$ penetrates the tissue and the reflected sound wave generated by the internal structure of the body or fetus is received by the ultrasound transducer, which analyzes the fetal heart rate $[65,66]$. 


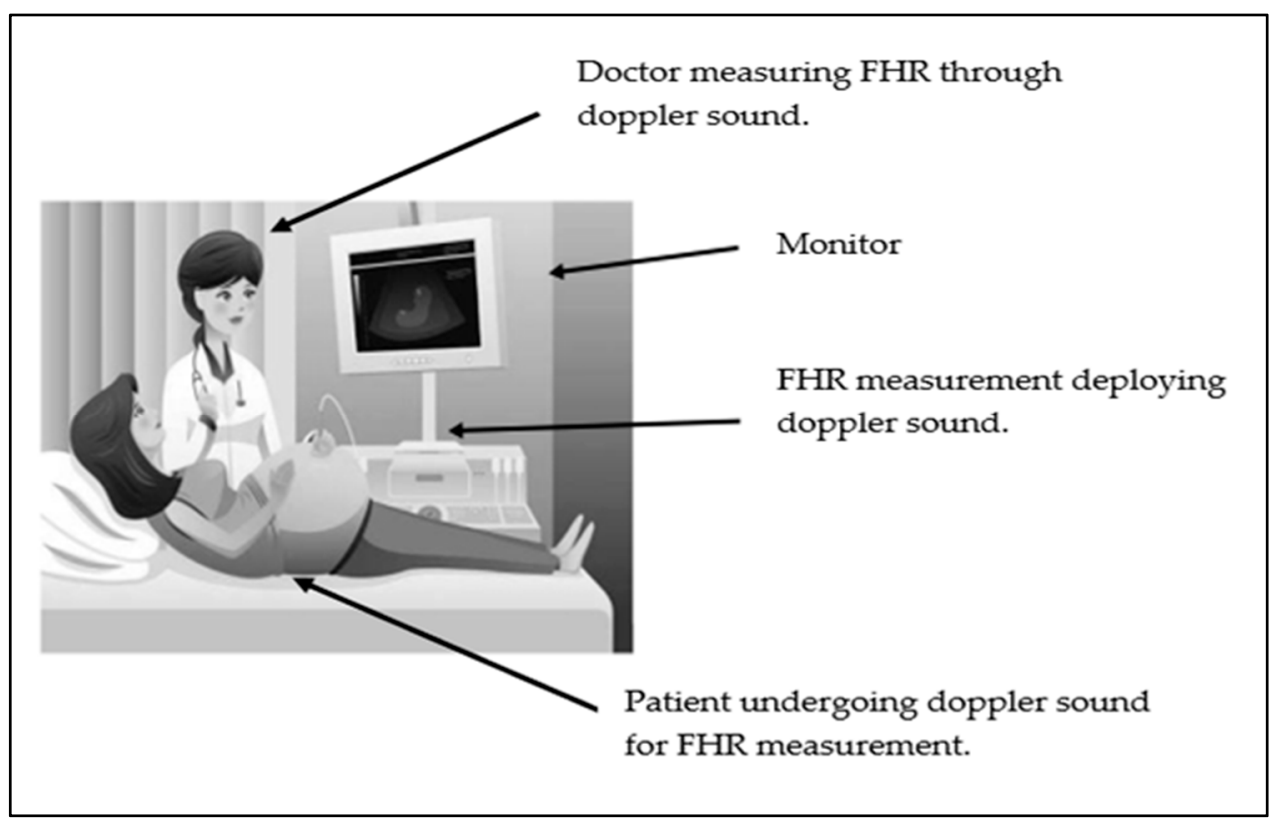

Figure 6. An illustration of the Doppler sound procedure for FHR monitoring.

\subsection{Fetalelectrocardiography (FECG)}

For the fetus, fetal electrocardiography (FECG) helps to analyze FHR and health conditions because the heart of the fetus is the first organ to develop during the first 3-4 weeks of pregnancy. To determine FHR of the fetus, several fetal monitoring techniques, both invasive and non-invasive, are used. However, considering the comfort of the patient, a non-invasive process for FECG is usually preferred [67-71]. In [72], Clifford et al. analyzed and evaluated the FECG device's accuracy in the context of fetal scalp electrodes (FSE) by comparing the results from the experiment. Thirty-two pregnant women were involved for data recording and the electrode placement was achieved following the configuration shown in Figure 7. The signal quality varied according to fetal positioning. However, the results of the study depicted that an average correlation of 0.96 was achieved in comparison to results obtained using invasive fetal scalp electrodes (FSE).

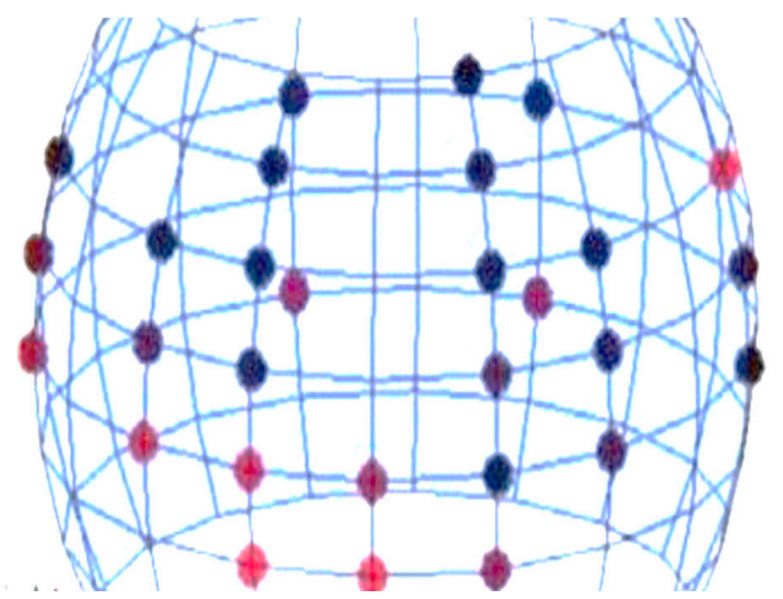

Figure 7. Electrode placement for FECG.

In [69], the authors used a commercially available FECG device AN24 to continuously monitor the fetus and to determine the fetus health. Some of the commercially available NIFECG devices are shown in Figure 8. 


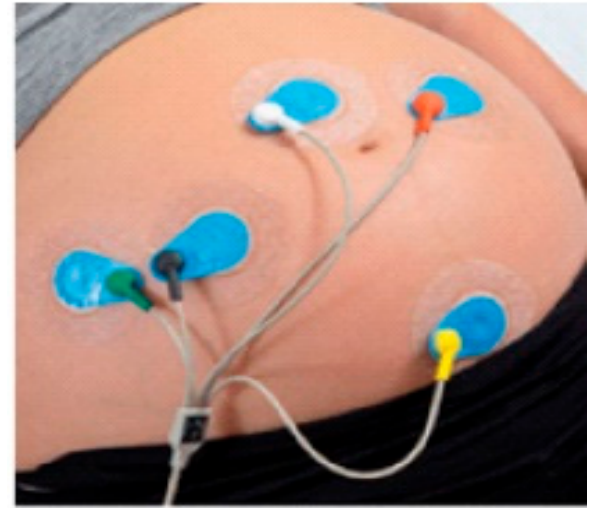

(a)

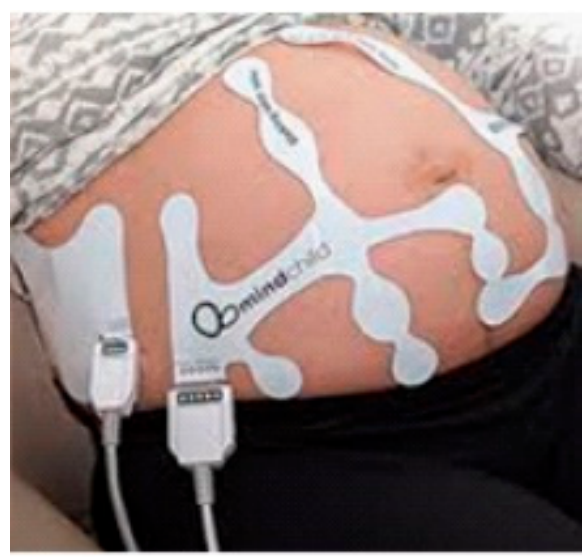

(c)

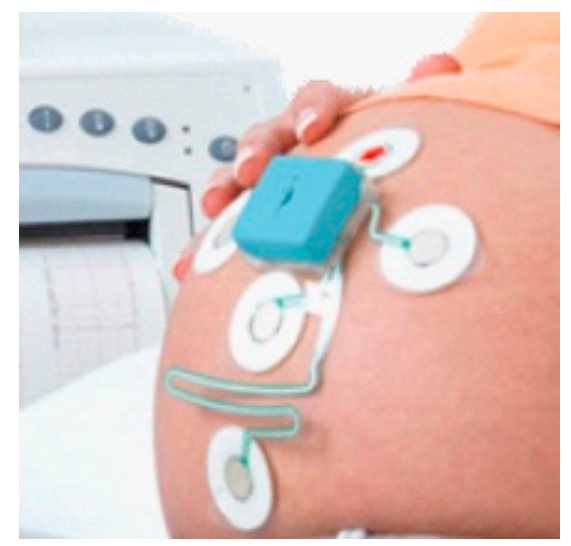

(b)

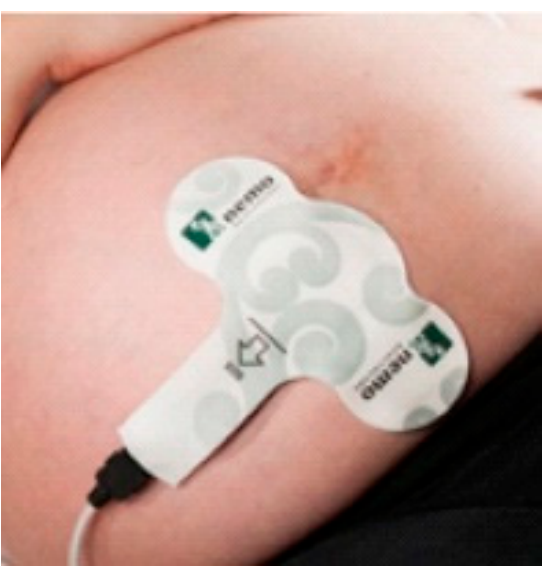

(d)

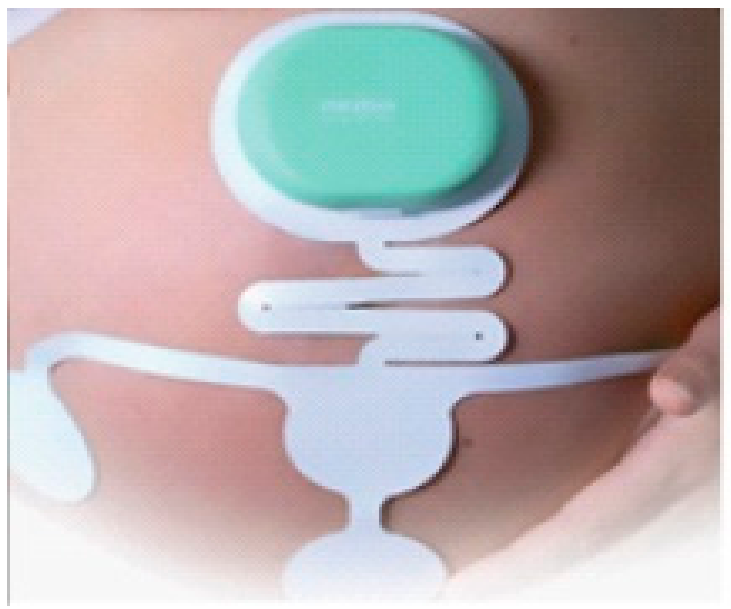

(e)

Figure 8. Examples of CE/FDA-certified commercially available NIFECG-based devices [69]. (a) Monica AN24, (b) Monica Novii Wireless Patch System, (c) MERIDIAN M110 Fetal Monitoring System, (d) PUREtrace, (e) Nemo Fetal Monitoring System (Reprinted with permission from Radek Martinek (2019) (2019, Creative Commons License)).

To understand the importance of electrode placement, a study was non-invasively conducted using the Monica AN24 Monitor with five electrodes [41,69,72-74]. It was observed that the non-invasive FECG was a preferred method to provide comfort to pregnant women in comparison to invasive FECG $[72,75,76]$. However, the results indicated that the signal quality of the FECG data obtained was affected by maternal cardiograph 
(MECG) artefacts and noise, but the FECG signal can be extracted after applying a set of filters [42,77-79]. In [7], a study was conducted using three pairs of electrodes which were placed on the abdomen of pregnant women. Complex continuous wavelet transform (CCWT) was deployed for the extraction of the FECG signal, using a four-stage procedure, as shown in Figure 9.

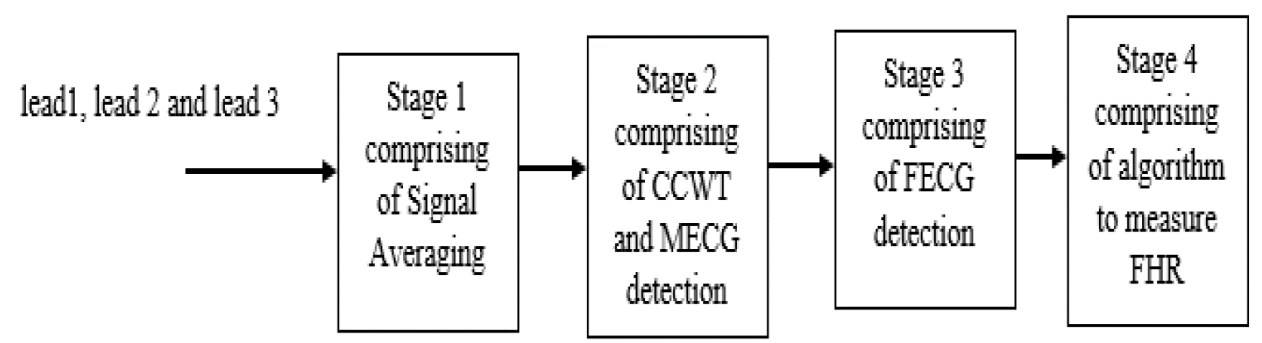

Figure 9. The proposed 4-stage fetal heart rate (FHR) extraction method [7].

In the first stage, the signals coming from the three pairs of electrodes were averaged, followed by stage two comprising of CCWT and MECG detection. The detection and extraction of FECG was carried out in stage three, while stage four focused on analyzing the fetal heart rate (FHR). Furthermore, a method to extract FECG from the MECG using a multivariate singular spectrum analysis (MSSA) was used, comprising of two stages known as decomposition and reconstruction. This technique helped the researchers in detecting the FHR and separating the unwanted noise both in stationary and non-stationary signals. The main advantage of FECG monitoring is that it can be used remotely, in a non-clinical environment with high simplicity $[7,80]$.

\section{Importance of Electrode Configurations for FECG Measurement \\ 4.1. Electrode Configurations}

Table 1 shows the comparison of electrode placement configurations over the maternal abdomen to monitor the FECG non-invasively. Comparisons have been made based on the number of electrodes placed on the maternal abdomen, and the filter parameter design used for pre-processing, such as bandwidth (BW), sampling frequency (Fs), resolution (R) of the A/D converter, and the gain $(\mathrm{G})$. 
Table 1. Comparison of different electrode placement for FECG monitoring.

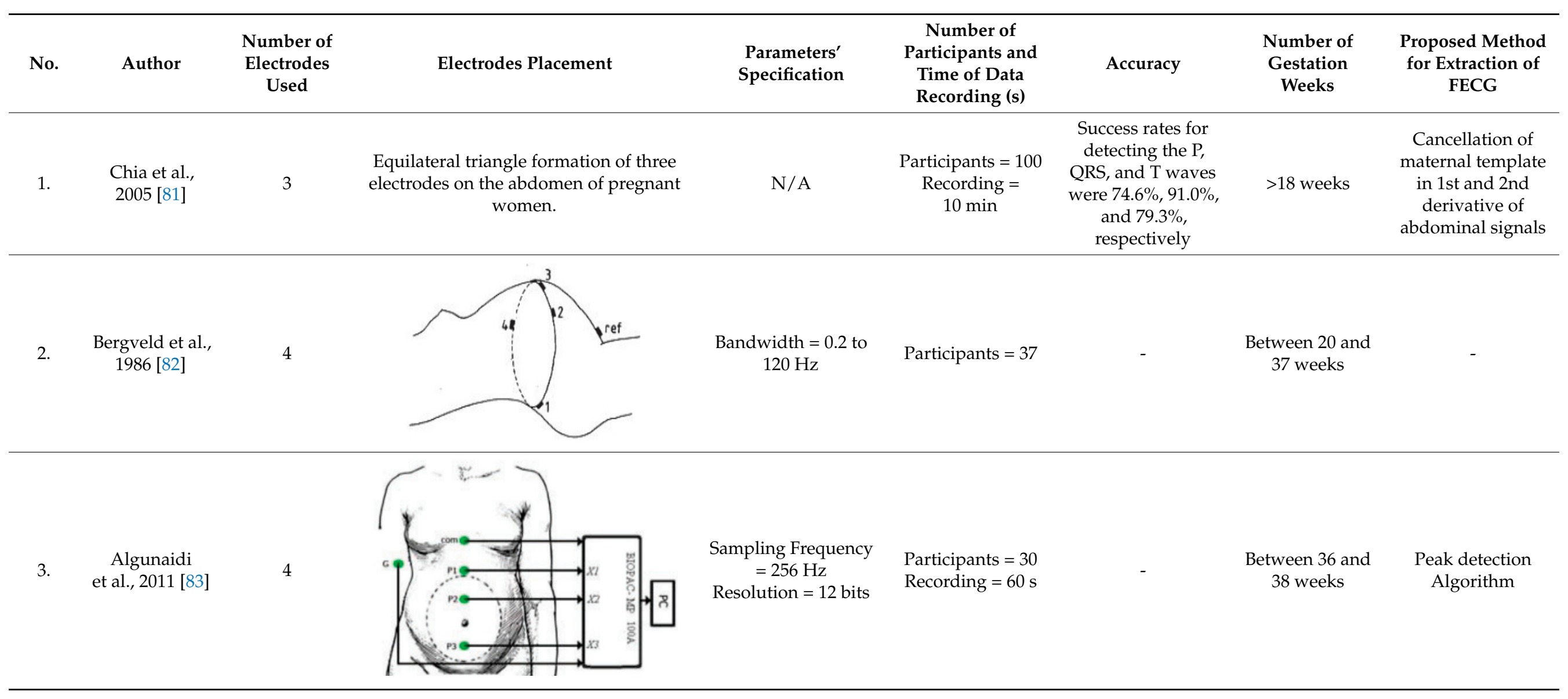


Table 1. Cont.

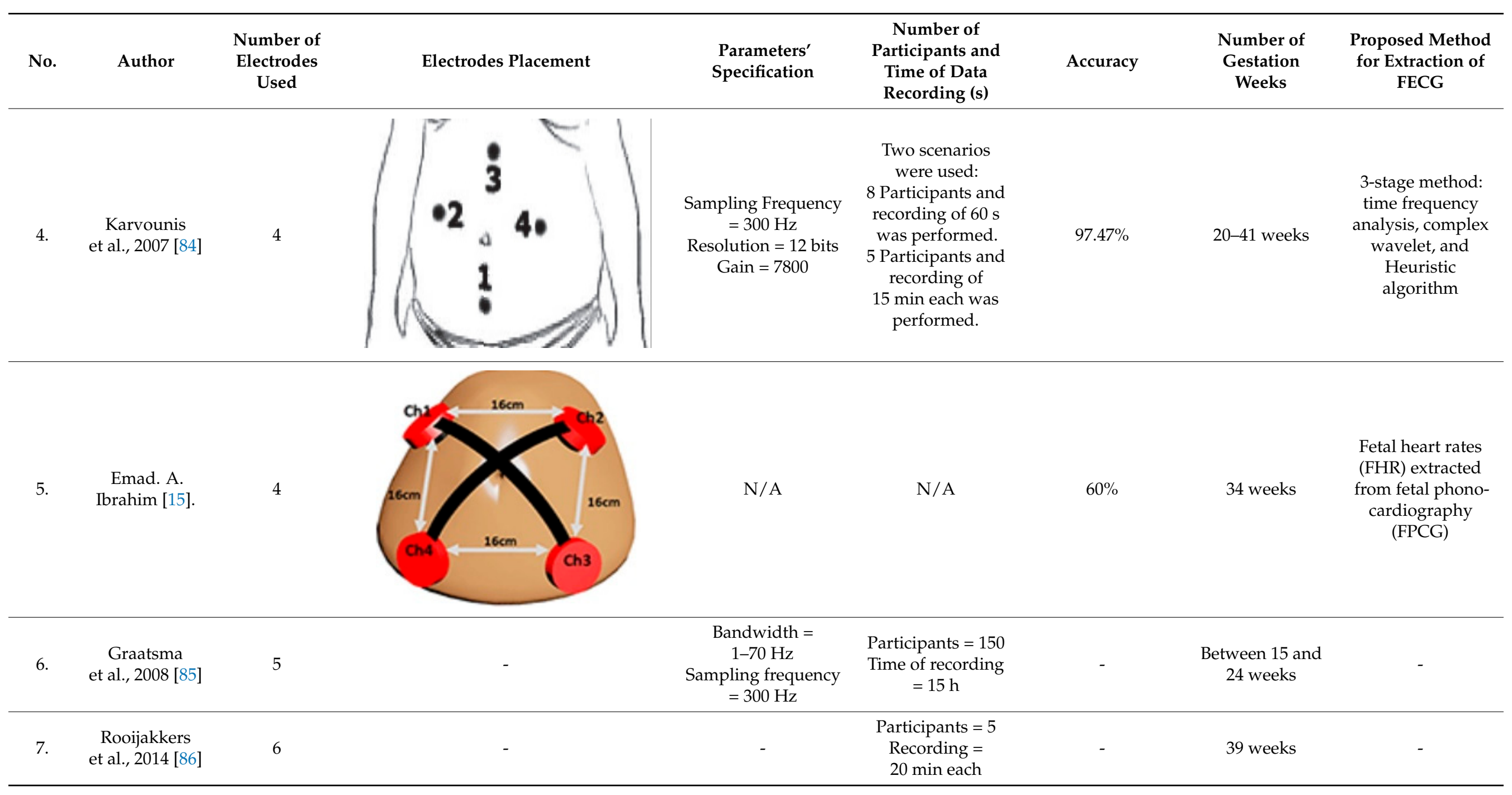


Table 1. Cont.

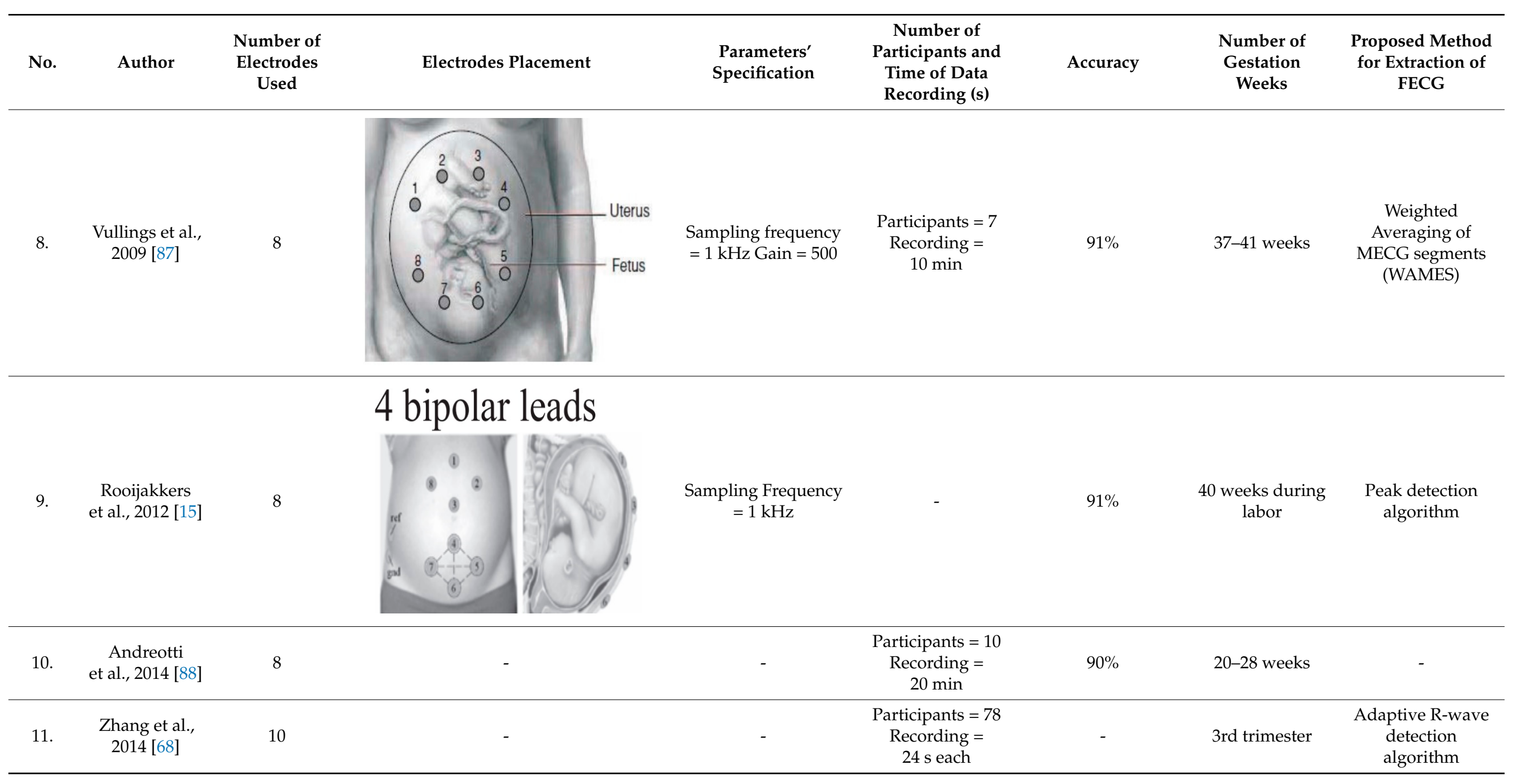


Table 1. Cont.

\begin{tabular}{|c|c|c|c|c|c|c|c|c|}
\hline No. & Author & $\begin{array}{c}\text { Number of } \\
\text { Electrodes } \\
\text { Used }\end{array}$ & Electrodes Placement & $\begin{array}{l}\text { Parameters' } \\
\text { Specification }\end{array}$ & $\begin{array}{c}\text { Number of } \\
\text { Participants and } \\
\text { Time of Data } \\
\text { Recording (s) }\end{array}$ & Accuracy & $\begin{array}{l}\text { Number of } \\
\text { Gestation } \\
\text { Weeks }\end{array}$ & $\begin{array}{c}\text { Proposed Method } \\
\text { for Extraction of } \\
\text { FECG }\end{array}$ \\
\hline 12. & $\begin{array}{l}\text { Martens et al., } \\
2007 \text { [89] }\end{array}$ & 13 & & Gain $=20$ & - & $85 \%$ & 9 weeks to labor & $\begin{array}{c}\text { Sequential } \\
\text { estimation method }\end{array}$ \\
\hline 13. & $\begin{array}{c}\text { Taylor et al., } \\
2003 \text { [90] }\end{array}$ & $\begin{array}{c}12-16 \\
\text { electrodes }\end{array}$ & 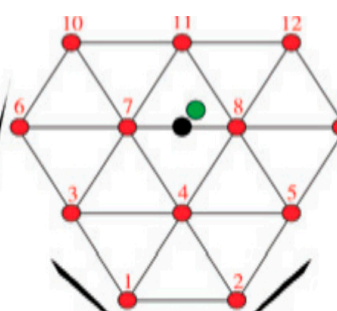 & $\begin{array}{l}\text { Sampling Frequency } \\
=512 \mathrm{~Hz}\end{array}$ & $\begin{array}{c}\text { Participants }=241 \\
\text { Recording }=250\end{array}$ & $85 \%$ & $\begin{array}{c}\text { Between } 15 \text { and } \\
33 \text { weeks }\end{array}$ & $\begin{array}{c}\text { Linear regression } \\
\text { to analyze QRS } \\
\text { intervals }\end{array}$ \\
\hline & & & - Ground & & & & & \\
\hline
\end{tabular}


Table 1. Cont.

\begin{tabular}{|c|c|c|c|c|c|c|c|c|}
\hline No. & Author & $\begin{array}{c}\text { Number of } \\
\text { Electrodes } \\
\text { Used }\end{array}$ & Electrodes Placement & $\begin{array}{l}\text { Parameters' } \\
\text { Specification }\end{array}$ & $\begin{array}{l}\text { Number of } \\
\text { Participants and } \\
\text { Time of Data } \\
\text { Recording (s) }\end{array}$ & Accuracy & $\begin{array}{l}\text { Number of } \\
\text { Gestation } \\
\text { Weeks }\end{array}$ & $\begin{array}{c}\text { Proposed Method } \\
\text { for Extraction of } \\
\text { FECG }\end{array}$ \\
\hline 14. & $\begin{array}{l}\text { Oostendorp } \\
\text { et al.,1989 [91] }\end{array}$ & 32 & & $\begin{array}{l}\text { Sampling Frequency } \\
=500 \mathrm{~Hz}\end{array}$ & $\begin{array}{l}\text { Participants = } 6 \\
\text { Recordings }=37\end{array}$ & - & $\begin{array}{c}\text { Between } 20 \text { and } \\
40 \text { weeks }\end{array}$ & $\begin{array}{l}\text { Homogeneous } \\
\text { volume } \\
\text { conduction model }\end{array}$ \\
\hline 15. & $\begin{array}{l}\text { Clifford et al., } \\
2011 \text { [92] }\end{array}$ & 32 & - & $\begin{array}{c}\text { Sampling Frequency } \\
=1 \mathrm{kHz}\end{array}$ & - & $91.2 \%$ & $\begin{array}{c}\text { Between } 35 \text { and } \\
41 \text { weeks }\end{array}$ & - \\
\hline
\end{tabular}


In Table 1, the comparison of different electrode placements is listed, which can further be divided into three different ranges, as listed in Table 2 [93].

Table 2. Different groups of electrode placement for NIFECG.

\begin{tabular}{|c|c|c|}
\hline No. of Electrodes & Discussion & Reference \\
\hline $\begin{array}{c}\text { Group 1: range of electrodes } \\
\text { between } 1 \text { and } 4\end{array}$ & $\begin{array}{l}\text { Advantages: For NIFECG monitoring, the electrodes are placed on the abdomen of } \\
\text { pregnant women. Hence, less are used for fetus monitoring, resulting in a simple } \\
\text { procedure without any discomfort to pregnant women. } \\
\text { Disadvantages: The data recorded does not provide detailed information about the } \\
\text { growth of the fetus. }\end{array}$ & {$[15,81-89]$} \\
\hline $\begin{array}{c}\text { Group 2, comprises a range } \\
\text { between } 10 \text { and } \\
20 \text { electrodes. }\end{array}$ & $\begin{array}{l}\text { Advantages: It is evidenced that the more electrodes placed on the abdomen of } \\
\text { pregnant women, the more comprehensive information can be gained about the } \\
\text { fetus, thus helping in analyzing the well-being of the fetus efficiently and effectively. } \\
\text { Disadvantages: Discomfort among the pregnant women due to several electrode } \\
\text { placements on the abdomen of pregnant women. }\end{array}$ & {$[89,90]$} \\
\hline $\begin{array}{l}\text { Group 3, comprises a range } \\
\text { of more than } 20 \text { electrodes }\end{array}$ & $\begin{array}{l}\text { Advantages: Provides the detailed information about the growth of the fetus. } \\
\text { Disadvantages: The deployment of } 20 \text { or more electrodes for FHR monitoring } \\
\text { involves a complex setup procedure in addition to being expensive. } \\
\text { Furthermore, results in skin irritation and severe discomfort to pregnant women due } \\
\text { to gel used in setting up the electrodes to establish effective electrode configuration. }\end{array}$ & {$[91,92]$} \\
\hline
\end{tabular}

In terms of detection accuracy of FHR, it was noticed from Table 1 that $97.47 \%$ was achieved with a four-electrode configuration through a three-step method, including time frequency analysis, complex wavelet, and Heuristic algorithm, at a sampling frequency of $300 \mathrm{~Hz}$, resolution of 12 bits, with a gain of 7800. An accuracy of $91 \%$ was obtained with 8-electrode and 32-electrode configurations at a sampling frequency of $1 \mathrm{KHz}$. Additionally, from Table 1, comparing the sequential method and liner regression method using 12-16 electrodes, an accuracy of $85 \%$ was achieved in FHR monitoring. The accuracy of the method used for NIFECG monitoring to determine the fetal heart rate is entirely dependent on the number of electrodes used for monitoring, placement of electrodes, gestation week, and parameters such as sampling frequency, resolution bits, and the gain. Furthermore, in a long-term monitoring, use of the conventional hydrogel electrodes would also significantly affect the accuracy since the hydrogel electrodes would dry out over time, thus affecting skin-electrode impedance.

\subsection{Electrode Types}

In FHR monitoring, the hydrogel electrodes improve ion conductivity and provide impedance matching between the skin and electrodes, thus minimizing noises and improving signal quality. However, hydrogel electrodes degrade and collect hair and dirt in addition to the possibility of causing skin irritation whilst being used, so they must be frequently replaced [94-97]. Moreover, the hydrogel layer on the electrodes tends to dry out over time so the long-term monitoring capability to monitor fetal heart rate will be compromised [98,99].

In view of the shortcomings of hydrogel electrodes in FHR monitoring, the smartbased electrodes have attracted more attention [99-101]. Smart textiles exploit the universality of textiles which cover all types of woven, nonwoven, and knitted materials/fabrics. In recent years, the interest in smart textiles as tools to continuously monitor physiological signals, such as ECG, has increased due to the high comfort and portability, unlike traditional monitoring systems using hydrogel electrodes which could create skin irritation [101,102].

Conventional textile manufacturing methods have been used to fabricate e-textile electrodes. An example shown in Figure 10a is the smart textile electrodes made through sewing conductive yarn to form electrodes. These electrodes are highly stretchable and flexible due to the nature of interlocking stitching patterns. Gold- or silver-coated yarn [103] as well as stainless yarn [104] are commonly used due to their high conductivity and the 
fact that they are readily available in the market [39]. However, the drawback is to build up a firm contact between skin and electrode surface without applying too much compression force through a strap.

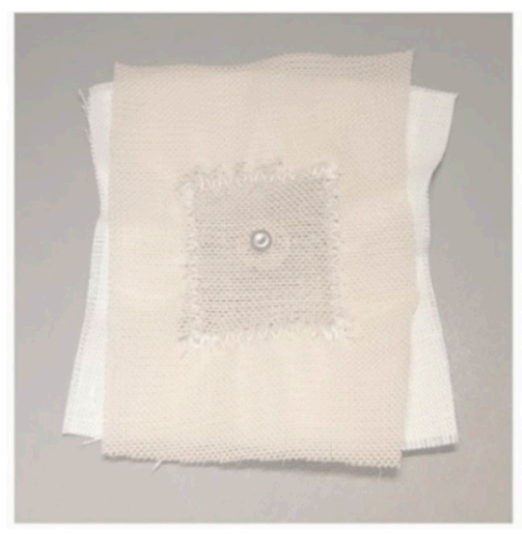

(a)

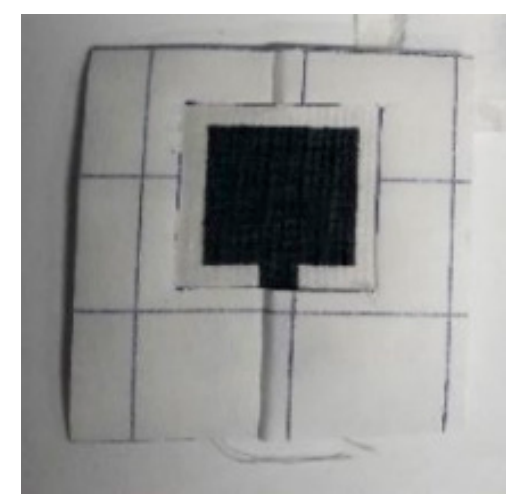

(b)

Figure 10. (a) Sewn ECG electrode; (b) screen printed ECG electrode. (Reprinted with permission from ref [39] Hasan, Muhammad (2009)).

In contrast, printing techniques (e.g., screen printing) have also been adapted to fabricate electrodes on textiles. The carbon-based silicone is commonly used as an interface between skin and conductive layer to enhance the skin impedance matching and to provide a solid/stable contact, thus improving the ECG signal quality and minimizing the noise. An example of screen-printed ECG electrodes is shown in Figure 10b, where carbon-loaded silicone is printed directly onto textile where it is needed to form the electrodes. These printed electrodes provide a higher degree of flexibility in terms of mass production, customization, impedance matching, and noise reduction. Vojtech et al. developed a three-electrode ECG monitoring system using prefabricated conductive textile $[39,105,106]$. In comparison to conductive textile or knitting, sewing enable enhanced freedom because of the broad range of patterns that can be used and the ability to overlap stitches to create a denser patch of conductivity within the fabric [107]. Kannaian et al. deployed sewing and embroidery to integrate silver-coated threads into fabrics to achieve electrodes for a textilebased ECG monitoring system [108]. There are several methods available to be employed to adhere the conductive substance to the chosen substrate: dip and dry, sputtering, screen printing, chemical etching, stencil printing, and permeation [106,107]. The electrode type and method deployed for ECG monitoring depend on the properties of the conductive substance and the substrate. However, the screen printing can produce higher printing volume with fewer printing cycles to achieve a stable conductive pattern on e-textile surfaces and is also a standard mass production method used in the textile industry.

\subsection{Current ECG Monitoring Development with Smart Textile Electrodes}

Traditionally, ECG monitoring relies upon adhesive hydrogel electrodes. There are some key challenges that arise with this type of electrode including discomfort to patients due to skin irritation caused by hydrogels $[109,110]$, difficult positioning when more electrodes are needed, and less accurate signal quality over longer period due to the degradation of hydrogel [105]. Over the past few years, novel concepts of using smart textile electrodes for monitoring ECG electrodes have emerged. Smart textiles-based electrodes are preferred for ECG monitoring as they can be deployed for longer term monitoring easily without any risk of hydrogel degradation and provide enhanced comfort to patients due to no skin irritation [111-113]. Some examples of current development in smart textile ECG electrodes are summarized in Table 3. 
Table 3. Some examples of smart textile ECG research.

\begin{tabular}{ccccc}
\hline No. & Method & Material & System Integration & Reference \\
\hline 1. & Knitting & Stainless steel & T-shirt & {$[113]$} \\
\hline 2. & $\begin{array}{c}\text { Knitting and } \\
\text { Embroidery }\end{array}$ & $\begin{array}{c}\text { Stainless steel } \\
\text { filament, nylon fabric }\end{array}$ & T-shirt & {$[114]$} \\
\hline 3. & Weaving and Knitting & Silver yarns & Chest band & {$[115]$} \\
\hline 4. & Screen printing & Silver ink & Chest band & {$[116]$} \\
\hline 5. & Electroless platting & Silver chloride & Smart garment & {$[117]$} \\
\hline
\end{tabular}

With the increase in cardiovascular diseases, there has been a growing interest in developing wearable devices, specifically smart textiles for ECG monitoring, that can continuously monitor cardiac activity without causing discomfort to patients [105]. A smart textile-based T-shirt achieved by knitting and embroidering stainless steel yarns on nylon fabric was deployed for long-term ECG monitoring, thus providing no skin irritation to patients, and enhancing the comfort to patients $[113,114]$. The authors of $[115,116]$ used the woven and screen-printed smart textile electrodes for ECG monitoring. The authors of [117] achieved a silver chloride electrode using electroless plating for the ECG monitoring.

However, the use of smart textile electrodes in FECG and NIFECG has yet to be reported due to the following barriers: (a) the optimized number of electrodes required for fetal heart rate monitoring needs to be investigated, and (b) the signal quality of FECG needs to be improved due to the small amplitude compared with MECG. The deployment of smart textile electrodes in non-invasive fetal electrocardiography (NIFECG) for fetal heart rate (FHR) monitoring will revolutionize the healthcare monitoring in a way that smart textile-based electrodes would provide enhanced comfort to patients and no skin irritation during long-term monitoring.

\section{Conclusions}

This paper provided a review of monitoring techniques including CTG, PPG, and Doppler sound, with the emphasis on fetal electrocardiogram (FECG), to detect fetal heart rate to determine the well-being and growth of the fetus. The importance of noninvasive FECG in contrast to invasive FECG in terms of comfort to patients was mentioned and highlighted in this paper. The different electrode configurations used in NIFECG monitoring were also discussed. It was shown that NIFFECG with fewer electrodes is more suitable for home use environments because the setup requires minimum preparation time, providing the essential FECG information and enhancing the comfort to the patients.

One of the key drawbacks of current NIFECG is the use of hydrogel electrodes, which tend to degrade over time. The positioning of these electrodes may also increase the complexity for being used at home by pregnant women. These drawbacks could be overcome by the introduction of smart textile-based electrodes, which are realized using either conventional textile manufacturing methods or printing. These electrodes do not need the assistance of a hydrogel layer to provide adhesion. Instead, the garment on which the electrodes are formed provides contraction to attach the electrodes against the skin. In addition, these electrodes are realized on the correct position and therefore the complex setup process is minimized. It is suggested that future research could focus on improving the contact between smart textile electrodes and skin. This is of importance since the quality of the FECG signal is an indicator of the well-being of the fetus to diagnose any chronic diseases at an early stage of pregnancy, and thus to help in taking the essential preventive and precautionary steps on time. Moreover, electrode number and positioning need to be investigated in the context of smart textiles to provide a compromise between wearability, useability, washability, and signal quality, which is a future research direction in NIFECG monitoring using smart textile electrodes. Therefore, the deployment of smart 
textile electrodes in NIFECG monitoring will play a crucial role in long-term monitoring and comfort to patients.

It is envisioned that the future perspective of smart textiles NIFECG in medical diagnosis will not be limited for the personal use because the device is believed to benefit the patients by carrying out the measurement either at hospitals by doctors or at home by themselves. There has been an ever-increasing utilization of cloud-based computing and Internet of things (IoT). Smart textile NIFECG should be light-weight and low-cost, providing data security and enhancing data transmission rate. Through cloud computing, the smart textile-based NIFECG measurement could be wirelessly connected to other medical IoT devices or a centralized hub, enabling accessing the essential health information from different locations.

Author Contributions: G.A. wrote the paper; Y.W. helped with revision; Both G.A. and Y.W. contributed to editing the paper. All authors have read and agreed to the published version of the manuscript.

Funding: This research was funded by Nottingham Trent University strategic research theme, Medical Technologies and Advanced Materials.

Institutional Review Board Statement: Not applicable.

Informed Consent Statement: Not applicable.

Data Availability Statement: Not applicable.

Conflicts of Interest: The authors declare no conflict of interest.

\section{References}

1. Ungureanu, G.; Gussi, I.; Wolf, W.; Tarălungă, D.; Pasca, S.; Strungaru, R. Prenatal Telemedicine Advances in Fetal Monitoring. 2011. Available online: https://scholar.google.com.hk/scholar?hl=en\&as_sdt=0\%2C5\&q=Ungureanu $\% 2 \mathrm{C}+\mathrm{Georgeta}+\% 26+$ Gussi $\% 2$ C +Ilinca+\%26+Wolf $\% 2 C+$ Werner+\%26+\%C8\%9Aar $\%$ C4 $\% 831$ ung $\%$ C4 $\% 83 \% 2 C+$ Drago $\%$ C $8 \% 99+\% 26+P a s c a \% 2 C+$ Sever+\%26+Strungaru\%2C+Rodica.+\%282011\%29.+Prenatal+Telemedicine+Advances+in+Fetal+Monitoring.+10.5772\%2F135 33.\&btnG $=$ (accessed on 23 June 2021). [CrossRef]

2. Hasan, M.A.; Reaz, M.B.I.; Ibrahimy, M.I.; Hussain, M.S.; Uddin, J. Detection and processing techniques of FECG signal for fetal monitoring. Biol. Proced. Online 2009, 11, 263-295. [CrossRef]

3. Chez, B.F.; Baird, S.M. Electronic Fetal Heart Rate Monitoring: Where Are We Now? J. Perinat. Neonatal Nurs. $2011,25,180-192$. [CrossRef]

4. Neilson, J.P. Fetal electrocardiogram (ECG) for fetal monitoring during labour. Cochrane Database Syst. Rev. 2006, 3. [CrossRef]

5. Freeman, R.K.; Garite, T.J.; Nageotte, M.P.; Miller, L.A. Fetal Heart Rate Monitoring; Lippincott Williams \& Wilkins: Philadelphia, PA, USA, 2012.

6. Peters, C.H.; ten Broeke, E.D.; Andriessen, P.; Vermeulen, B.; Berendsen, R.C.; Wijn, P.F.; Oei, S.G. Beat-to-beat detection of fetal heart rate: Doppler ultrasound cardiotocography compared to direct ECG cardiotocography in time and frequency domain. Physiol. Meas. 2004, 25, 585. [CrossRef] [PubMed]

7. Vullings, R.; Peters, C.; Mischi, M.; Oei, G.; Bergmans, J. Maternal ECG removal from non-invasive fetal ECG recordings. In Proceedings of the EMBS'06. 28th Annual International Conference of the IEEE Engineering in Medicine and Biology Society, New York, NY, USA, 30 August-3 September 2006; pp. 1394-1397.

8. Hon, E.H. Apparatus for continuous monitoring of the fetal heart rate. Yale J. Biol. Med. 1960, $32,397$.

9. Fetal Heart Monitoring. Journal of Obstetric, Gynecologic \& Neonatal Nursing. 2018. Available online: https://www.jognn.org/ article/S0884-2175(18)30322-8/fulltext (accessed on 23 June 2021). [CrossRef]

10. Jezewski, J.; Roj, D.; Wrobel, J.; Horoba, K. A novel technique for fetal heart rate estimation from Doppler ultrasound signal. Biomed. Eng. Online 2011, 10. [CrossRef]

11. Black, R.S.; Campbell, S. Cardiotocography versus Doppler. Ultrasound Obstet. Gynecol. 1997, 9, 148-151. [CrossRef] [PubMed]

12. Peters, M.; Crowe, J.; Piéri, J.F.; Quartero, H.; Hayes-Gill, B.; James, D.; Shakespeare, S. Monitoring the fetal heart non-invasively: A review of methods. J. Perinat. Med. 2001, 29, 408-416. [CrossRef] [PubMed]

13. Strasburger, J.F.; Cheulkar, B.; Wakai, R.T. Magnetocardiography for fetal arrhythmias. Heart Rhythm Off. J. Heart Rhythm Soc. 2008, 5, 1073. [CrossRef]

14. Adithya, P.C.; Sankar, R.; Moreno, W.A.; Hart, S. Trends in fetal monitoring through phonocardiography: Challenges and future directions. Biomed. Signal Process. Control 2017, 33, 289-305. [CrossRef]

15. Andreotti, F.; Riedl, M.; Himmelsbach, T.; Wedekind, D.; Wessel, N.; Stepan, H.; Schmieder, C.; Jank, A.; Malberg, H.; Zaunseder, S. Robust fetal ECG extraction and detection from abdominal leads. Physiol. Meas. 2014, 35, 1551-1568. [CrossRef] 
16. Assaleh, K. Extraction of fetal electrocardiogram using adaptive neuro-fuzzy interference systems. IEEE Trans. Biomed. Eng. 2007, 54, 59-68. [CrossRef]

17. Behar, J.; Johnson, A.; Clifford, G.D.; Oster, J. A comparison of single channel fetal ECG extraction methods. Ann. Biomed. Eng. 2014, 42, 1340-1353. [CrossRef] [PubMed]

18. Gao, X. On the improved correlative prediction scheme for aliased electrocardiogram (ECG) data compression. In Proceedings of the 2012 Annual International Conference of the IEEE Engineering in Medicine and Biology Society (EMBC), San Diego, CA, USA, 28 August-1 September 2012; pp. 6180-6183.

19. Ghodsi, M.; Hassani, H.; Sanei, S. Extracting fetal heart signal from noisy maternal ECG by singular spectrum analysis. J. Stat. Interface Spec. Issue Appl. SSA 2010, 3, 399-411. [CrossRef]

20. Hyvarinen, A. Fast and robust fixed-point algorithms for independent component analysis. IEEE Trans. Neural Netw. 1999, 10, 626-634. [CrossRef]

21. Immanuel, J.J.R.; Prabhu, V.; Christopheraj, V.J.; Sugumar, D.; Vanathi, P.T. Separation of maternal and fetal ECG signals from the mixed source signal using FASTICA. Procedia Eng. 2012, 30, 356-363. [CrossRef]

22. Jafari, M.G.; Chambers, J.A. Fetal electrocardiogram extraction by sequential source separation in the wavelet domain. IEEE Trans. Biomed. Eng. 2005, 52, 390-400. [CrossRef]

23. Kropfl, M.; Modre-Osprian, R.; Schreier, G.; Hayn, D. A robust algorithm for fetal QRS detection using non-invasive maternal abdominal ECGs. Comput. Cardiol. 2013, 40, 313-316.

24. Kumar, P.; Sharma, S.K.; Prasad, S. Detection of FECG from multivariate abdominal recordings using wavelets and neuro-fuzzy systems. Int. J. Eng. Adv. Technol. Stud. 2013, 2, 45-51.

25. Melillo, P.; Santoro, D.; Vadursi, M. Detection and compensation of inter-channel time offsets in indirect fetal ECG sensing. IEEE Sens. J. 2014, 14, 2327-2334. [CrossRef]

26. Panigrahy, D.; Sahu, P.K. Extraction of fetal electrocardiogram (ECG) by extended state Kalman filtering and adaptive neuro-fuzzy inference system (ANFIS) based on single channel abdominal recording. Sadhana 2015, 40, 1091-1104. [CrossRef]

27. Poian, G.D.; Bernardini, R.; Rinaldo, R. Separation and analysis of fetal-ECG signals from compressed sensed abdominal ECG recordings. IEEE Trans. Biomed. Eng. 2016, 63, 1269-1279. [CrossRef] [PubMed]

28. Reza, S.; Shamsollahi, M.B.; Jutten, C.; Clifford, G.D. A nonlinear Bayesian filtering framework for ECG denoising. IEEE Trans. Biomed. Eng. 2007, 54, 2172-2185.

29. Rooijakkers, M.J.; Rabotti, C.; de Lau, H.; Oei, S.G.; Bergmans, J.W.M.; Mischi, M. Feasibility study of a new method for low-complexity fetal movement detection from abdominal ECG recordings. IEEE J. Biomed. Health Inform. 2016, 20, 1361-1368. [CrossRef]

30. Selvaraj, R.; Kanagaraj, B. A multi-stage adaptive singular value decomposition approach for fetal ECG signal extraction in multichannel input system for prenatal health monitoring. Asian J. Inf. Technol. 2016, 15, 1049-1055.

31. Sameni, R.; Clifford, G.D. A review of fetal ECG signal processing; issues and promising directions. Open Pacing Electrophysiol. Ther. J. 2010, 3, 4. [CrossRef]

32. von Steinburg, S.P.; Boulesteix, A.; Lederer, C.; Grunow, S.; Schiermeier, S.; Hatzmann, W.; Daumer, M. What is the "normal" fetal heart rate. PeerJ 2013. [CrossRef]

33. Silva, I.; Behar, J.; Sameni, R.; Zhu, T.-T.; Oster, J.; Clifford, G.D.; Moody, G.B. Noninvasive fetal ECG: The PhysioNet/computing in cardiology challenge 2013. In Proceedings of the IEEE Conference of Computing in Cardiology (CinC), Zaragoza, Spain, 22-25 September 2013; pp. 149-152.

34. Song, S.; Rooijakkers, M.J.; Harpe, P.; Rabotti, C.; Mischi, M.; van Roermund, A.H.M.; Cantatore, E. A noise reconfigurable current-reuse resistive feedback amplifier with signal-dependent power consumption for fetal ECG monitoring. IEEE Sens. J. 2016, 16, 8304-8313. [CrossRef]

35. Tadi, M.J.; Lehtonen, E.; Hurnanen, T.; Koskinen, J.; Eriksson, J.; Pänkäälä, M.; Teräs, M.; Koivisto, T. A real-time approach for heart rate monitoring using a Hilbert transform in seismocardiograms. Physiol. Meas. 2016, 37, 1885-1909. [CrossRef]

36. Yeh, H.-M.; Chang, Y.-C.; Lin, C.; Yeh, C.-H.; Lee, C.-N.; Shyu, M.-K.; Hung, M.-H.; Hsiao, P.-N.; Wang, Y.-H.; Tseng, Y.-H.; et al. A new method to derive fetal heart rate from maternal abdominal electrocardiogram monitoring fetal heart rate during cesarean section. PLOS ONE 2015, 10, e0117509.

37. Zheng, W.; Li, X.-L.; Wei, X.-Y.; Liu, H.-X. Foetal ECG extraction by support vector regression. Electron. Lett. $2016,52,506-507$.

38. Adam, J. The Future of Fetal Monitoring. Rev. Obstet. Gynecol. 2012, 5, e132.

39. Hasan, M.; Ibrahimy, M.; Reaz, M. Fetal ECG Extraction from Maternal Abdominal ECG Using Neural Network. J. Softw. Eng. Appl. 2009, 2, 330-334. [CrossRef]

40. Graatsma, E.M.; Jacod, B.C.; Van Egmond, L.A.J.; Mulder, E.J.H.; Visser, G.H.A. Fetal electrocardiography: Feasibility of long-term fetal heart rate recordings. BJOG Int. J. Obstet. Gynaecol. 2009, 116, 334338. [CrossRef]

41. Graatsma, E.M. Monitoring of Fetal Heart Rate and Uterine Activity; Utrecht University: Utrecht, The Netherlands, 2010.

42. Karvounis, E.C.; Papaloukas, C.; Fotiadis, D.I.; Michalis, L.K. Fetal heart rate extraction from composite maternal ECG using complex continuous wavelet transform. In Computers in Cardiology; IEEE: Piscataway, NJ, USA, 2004; pp. 737-740.

43. Zhongliang, L.U.O. Fetal Electrocardiogram Extraction using Blind Source Separation and Empirical Mode Decomposition. J. Comput. Inf. Syst. 2012, 8, 4825-4833. 
44. Zheng, W.; Liu, H.; He, A.; Ning, X.; Cheng, J. Singlelead fetal electrocardiogram estimation by means of combining Rpeak detection, resampling and comb filter. Med. Eng. Phys. 2010, 32, 708-719. [CrossRef] [PubMed]

45. Martínek, R.; Zidek, J. A System for Improving the Diagnostic Quality of Fetal Electrocardiogram. Prz. Elektrotech. 2012, 164-173. Available online: https://scholar.google.com.tw/scholar?hl=en\&as_sdt=0\%2C5\&q=46.\%09Mart $\%$ C3 $\%$ ADnek $\% 2 C+R . \% 2 C+$ $\% 26+Z i d e k \% 2 C+J .+\% 282012 \% 29 .+A+$ System + for + Improving+the+Diagnostic+Quality + of + Fetal+Electrocardiogram.+ Przegl $\%$ C4\%85d+El-ektrotechniczny\%2C+164-173.\&btnG= (accessed on 23 June 2021).

46. Sree, T.H.; Garimella, M.; Bandari, A.; Patel, I. Microcontroller Based Fetal Heart Rate Monitoring using Intelligent Biosystem. In Proceedings of the 3rd International Conference on Electronics, Biomedical Engineering and Its Applications (ICEBEA'2013), Singapore, 29-30 April 2013.

47. Sun, Y.; Hu, S.; Azorin-Peris, V.; Greenwald, S.; Chambers, J.; Zhu, Y. Motion-compensated noncontact imaging photoplethysmography to monitor cardiorespiratory status during exercise. J. Biomed. Opt. 2011, 16, 077010. [CrossRef] [PubMed]

48. Nitzan, M.; Khanokh, B.; Slovik, Y. The difference in pulse transit time to the toe and finger measured by photoplethysmography. Physiol. Meas. 2002, 23, 85. [CrossRef] [PubMed]

49. Gan, K.B.; Ali, M.M.; Zahedi, E. Two Channel Abdominal PPG Instrumentation. In Proceedings of the 4th Kuala Lumpur International Conference on Biomedical Engineering 2008, Kuala Lumpur, Malaysia, 25-28 June 2008; Springer: Berlin/Heidelberg, Germany, 2008; pp. 691-693.

50. Gan, K.B.; Zahedi, E.; Ali, M.A.M. Transabdominal fetal heart rate detection using NIR photopleythysmography: Instrumentation and clinical results. IEEE Trans. Biomed. Eng. 2009, 56, 2075-2082. [PubMed]

51. Gan, K.B.; Zahedi, E.; Ali, M.M. Feasibility of Fetal Photoplethysmography Signal Extraction using Adaptive Noise Cancelling. In Proceedings of the 3rd Kuala Lumpur International Conference on Biomedical Engineering 2006, Kuala Lumpur, Malaysia, 11-14 December 2006; Springer: Berlin/Heidelberg, Germany, 2006; pp. 387-390.

52. Ahsan, K.; Emad, I.; Sayaka, O.; Yoshitaka, K. Validation of beat by beat fetal heart signals acquired from four-channel fetal phonocardiogram with fetal electrocardiogram in healthy late pregnancy. Sci. Rep. 2018, 8. [CrossRef]

53. Heart Rate. Available online: http://fabacademy.org/archives/2013/students/contonente.javier/week16/week16.html (accessed on 16 February 2021).

54. Cesarelli, M.; Romano, M.; Bifulco, P.; Fedele, F.; Bracale, M. An algorithm for the recovery of fetal heart rate series from CTG data. Comput. Biol. Med. 2007, 37, 663669. [CrossRef]

55. Williams, B.; Arulkumaran, S. Cardiotocography and medicolegal issues. Best Pract. Res. Clin. Obstet. Gynaecol. 2004, 18, 457-466. [CrossRef]

56. Ugwumadu, A. Understanding cardiotocographic patterns associated with intrapartum fetal hypoxia and neurologic injury. Best Pract. Res. Clin. Obstet. Gynaecol. 2013, 27, 509-536. [CrossRef]

57. Alfirevic, Z.; Devane, D.; Gyte, G.M. Continuous cardiotocography (CTG) as a form of electronic fetal monitoring (EFM) for fetal assessment during labour. Cochrane Database Syst. Rev. 2006, 3. [CrossRef]

58. Paul, H.; Rik, V.; Alexander, K.; Jan, B.; van Judith, L.; Piero, T.; Massimo, M. Doppler Ultrasound Technology for Fetal Heart Rate Monitoring: A Review. IEEE Trans. Ultrason. Ferroelectr. Freq. Control 2019. [CrossRef]

59. Pregnancy and Antental Care. Available online: https://steemit.com/health/@doctorhealth/pregnancy-antenatal-care-andcounselling (accessed on 10 February 2021).

60. Voicu, I.; Ménigot, S.; Kouamé, D.; Girault, J. New Estimators and Guidelines for Better Use of Fetal Heart Rate Estimators with Doppler Ultrasound Devices. Comput. Math. Methods Med. 2014, 2014. [CrossRef] [PubMed]

61. Karlsson, B.; Foulquière, K.; Kaluzynski, K.; Tranquart, F.; Fignon, A.; Pourcelot, D.; Berson, M.; Pourcelot, L. The DopFet system: A new ultrasonic Doppler system for monitoring and characterization of fetal movement. Ultrasound Med. Biol. 2000, 26, 1117-1124. [CrossRef]

62. Jeżewski, J.; Wróbel, J.; Horoba, K.; Cholewa, D.; Gacek, A.; Kupka, T.; Matonia, A. Monitoring of mechanical and electrical activity of fetal heart: The nature of signals. Arch. Perinat. Med. 2002, 8, 40-46.

63. Van Geijn, H.P.; Copray, F.J.A. A Critical Appraisal of Fetal Surveillance; Academic Hospital of the Free University: Amsterdam, The Netherlands, 1994.

64. Crowe, J.A.; Herbert, J.M.; Huang, X.B.; Reed, N.; Woolfson, M.S.; Rassi, D.; Zhuravlev, Y.E.; Emery, S.J. Sequential recording of the abdominal fetal electrocardiogram and magnetocardiogram. Physiol. Meas. 1995, 16, 43-47. [CrossRef]

65. Goodlin, R.C. History of fetal monitoring. Am. J. Obstet. Gynecol. 1979, 133, 323-352. [CrossRef]

66. Solum, T.; Ingemarsson, I.; Nygren, A. The accuracy of abdominal ECG for fetal electronic monitoring. J. Perinat. Med. 1980, 8 , 142-149. [CrossRef]

67. Khamene, A.; Negahdaripour, S. A new method for the extraction of fetal ECG from the composite abdominal signal. Biomed. Eng. IEEE Trans. 2000, 47, 507-516. [CrossRef] [PubMed]

68. Clifford, G.; Sameni, R.; Ward, J.; Robinson, J.; Wolfberg, A.J. Clinically accurate fetal ECG parameters acquired from maternal abdominal sensors. Am. J. Obstet. Gynecol. 2011, 205, 47.e1-47.e5. [CrossRef]

69. Kahankova, R.; Martinek, R.; Jaros, R.; Behbehani, K.; Matonia, A.; Jezewski, M.; Behar, J.A. A Review of Signal Processing Techniques for Non-Invasive Fetal Electrocardiography. IEEE Rev. Biomed. Eng. 2020, 13, 51-73. [CrossRef]

70. Monica Healthcare. Available online: http:/ /www.monicahealthcare.com/ (accessed on 6 August 2019).

71. Mindchild. Available online: http://www.mindchild.com/ (accessed on 6 August 2019). 
72. Nemo Healthcare, Community Research and Development Information Service. Available online: https://nemohealthcare.com/en/ (accessed on 6 August 2019).

73. Cohen, W.R.; Ommani, S.; Hassan, S.; Mirza, F.G.; Solomon, M.; Brown, R.; Schifrin, B.S.; Himsworth, J.M.; Hayes-Gill, B.R. Accuracy and reliability of fetal heart rate monitoring using maternal abdominal surface electrodes. Acta Obstet. Gynecol. Scand. 2012, 91, 1306-1313. [CrossRef]

74. Hon, E.; Hess, O. The clinical value of fetal electrocardiography. Am. J. Obstet. Gynecol. 1960, 79, 1012-1023. [CrossRef]

75. Algunaidi, M.S.M.; Ali, M.M.; Gan, K.B.; Zahedi, E. Fetal heart rate monitoring based on adaptive noise cancellation and maternal QRS removal window. Eur. J. Sci. Res. 2009, 27, 565-575.

76. Goell, P.; Rai, S.; Chandra, M.; Gupta, V.K. Analysis of LMS Algorithm in Wavelet Domain. In Proceedings of the Conference on Advances in Communication and Control Systems Systems (CAC2S 2013), Dehradun, India, 6-8 April 2013.

77. Unser, M.; Aldroubi, A. A review of wavelets in biomedical applications. Proc. IEEE 1996, 84, 626-638. [CrossRef]

78. Abdulhay, E.W.; Oweis, R.J.; Alhaddad, A.M.; Sublaban, F.N.; Radwan, M.A.; Almasaeed, H.M. Non-Invasive Fetal Heart Rate Monitoring Techniques: Review article. Biomed. Sci. Eng. 2014, 2, 53-67.

79. Chia, E.L.; Ho, T.F.; Rauff, M.; Yip, W.C.L. Cardiac time intervals of normal fetuses using noninvasive fetal electrocardiography. Prenat. Diagn. 2005, 25, 546-552. [CrossRef] [PubMed]

80. Algunaidi, M.S.; Ali, M.M.; Islam, M.F. Evaluation of an improved algorithm for fetal QRS detection. Int. J. Phys. Sci. 2011, 6, 213-220.

81. Karvounis, E.C.; Tsipouras, M.G.; Fotiadis, D.I.; Naka, K.K. An Automated Methodology for Fetal Heart Rate Extraction from the Abdominal Electrocardiogram. IEEE Trans. Inf. Technol. Biomed. 2007, 11, 628-638. [CrossRef] [PubMed]

82. Rooijakkers, M.J.; Rabotti, C.; Oei, S.G.; Mischi, M. Low-complexity R-peak detection for ambulatory fetal monitoring. Physiol. Meas. 2012, 33, 1135-1150. [CrossRef] [PubMed]

83. Rooijakkers, M.J.; Song, S.; Rabotti, C.; Oei, S.G.; Bergmans, J.W.M.; Cantatore, E.; Mischi, M. Influence of Electrode Placement on Signal Quality for Ambulatory Pregnancy Monitoring. Comput. Math. Methods Med. 2014, 2014, 960980. [CrossRef]

84. Vullings, R.; Peters, C.H.L.; Sluijter, R.J.; Mischi, M.; Oei, S.G.; Bergmans, J.W.M. Dynamic segmentation and linear prediction for maternal ECG removal in antenatal abdominal recordings. Physiol. Meas. 2009, 30, 291-307. [CrossRef] [PubMed]

85. Jie-Min, Z.; Xiao-Lin, H.; Qun, G.; Tie-Bing, L.; Ping, L.; Ying, Z.; Hong-Xing, L. Some regularity on how to locate electrodes for higher fECG SNRs. Chin. Phys. B 2015, 24, 038702.

86. Martens, S.M.M.; Rabotti, C.; Mischi, M.; Sluijter, R.J. A robust fetal ECG detection method for abdominal recordings. Physiol. Meas. 2007, 28, 373-388. [CrossRef] [PubMed]

87. Taylor, M.J.; Smith, M.J.; Thomas, M.; Green, A.R.; Cheng, F.; Oseku-Afful, S.; Wee, L.Y.; Fisk, N.M.; Gardiner, H.M. Non-invasive fetal electrocardiography in singleton and multiple pregnancies. BJOG Int. J. Obstet. Gynaecol. 2003, 110, 668-678. [CrossRef]

88. Oostendorp, T.F.; Van Oosterom, A.; Jongsma, H.W. The fetal ECG throughout the second half of gestation. Clin. Phys. Physiol. Meas. 1989, 10, 147-160. [CrossRef]

89. Marchon, N.; Naik, G. Electrode positioning for monitoring Fetal ECG: A review. In Proceedings of the 2015 International Conference on Information Processing (ICIP), Pune, India, 16-19 December 2015; pp. 5-10. [CrossRef]

90. Strazdienè, E.; Blaževič, P.; Vegys, A.; Dapkūnienè, K. New Tendencies of Wearable Electronics Application in Smart Clothing. Electron. Electr. Eng. 2007, 73, 21-24.

91. Rodrigues, R. Fetal beat detection in abdominal ECG recordings: Global and time adaptive approaches. Physiol. Meas. 2014, 35, 1699-1711. [CrossRef] [PubMed]

92. Panigrahy, D.; Rakshit, M.; Sahu, P.K. An efficient method for fetal ECG extraction from single channel abdominal ECG. In Proceedings of the 2015 International Conference on Industrial Instrumentation and Control (ICIC), Pune, India, 28-30 May 2015; pp. 1083-1088. [CrossRef]

93. Kennedy, R.G. Electronic fetal heart rate monitoring: Retrospective reflections on a twentieth-century technology. J. R. Soc. Med. 1998, 91, 244-250. [CrossRef] [PubMed]

94. Ivanoska-Dacikj, A.; Stachewicz, U. Smart textiles and wearable technologies-Opportunities offered in the fight against pandemics in relation to current COVID-19 state. Rev. Adv. Mater. Sci. 2020, 59, 487-505. [CrossRef]

95. Hughes-Riley, T.; Dias, T.; Cork, C. A Historical Review of the Development of Electronic Textiles. Fibers 2018, 6, 34. [CrossRef]

96. Tsukada, Y.T.; Tokita, M.; Murata, H.; Hirasawa, Y.; Yodogawa, K.; Iwasaki, Y.-K.; Kasai, N.; Shimizu, W.; Nakashima, H.; Tsukada, S. Validation of wearable textile electrodes for ECG monitoring. Heart Vessels 2019, 34, 1203-1211. [CrossRef]

97. Paul, G.; Torah, R.; Beeby, S.; Tudor, J. A printed, dry electrode frank configuration vest for ambulatory vectorcardiographic monitoring. Smart Mater. Struct. 2016, 26, 025029. [CrossRef]

98. Komolafe, A.; Torah, R.; Wei, Y.; Nunes-Matos, H.; Li, M.; Hardy, D.; Dias, T.; Tudor, M.; Beeby, S. Integrating Flexible Filament Circuits for E-Textile Applications. Adv. Mater. Technol. 2019, 4, 1900176. [CrossRef]

99. Schwarz, A.; Hakuzimana, J.; Kaczynska, A.; Banaszczyk, J.; Westbroek, P.; McAdams, E.; Moody, G.; Chronis, Y.; Priniotakis, G.; De Mey, G.; et al. Gold coated para-aramid yarns through electroless deposition. Surf. Coat. Technol. 2010, 204, 1412-1418. [CrossRef]

100. Odhiambo, S.A.; De Mey, G.; Hertleer, C.; Schwarz, A.; van Langenhove, L. Discharge characteristics of poly(3,4-ethylene dioxythiophene): Poly(styrenesulfonate) (PEDOT:PSS) textile batteries; comparison of silver coated yarn electrode devices and pure stainless steel filament yarn electrode devices. Text. Res. J. 2014, 84, 347-354. [CrossRef] 
101. An, X.; Stylios, G.K. A Hybrid Textile Electrode for Electrocardiogram (ECG) Measurement and Motion Tracking. Materials 2018, 11, 1887. [CrossRef]

102. Achilli, A.; Pani, D.; Bonfiglio, A. Characterization of Screen-Printed Textile Electrodes Based on Conductive Polymer for ECG Acquisition; IEEE: New York, NY, USA, 2017. [CrossRef]

103. Lee, Y.-D.; Chung, W.-Y. Wireless sensor network based wearable smart shirt for ubiquitous health and activity monitoring. Sens. Actuator B Chem. 2009, 140, 390-395. [CrossRef]

104. Acar, G.; Ozturk, O.; Golparvar, A.J.; Elboshra, T.A.; Böhringer, K.; Yapici, M.K. Wearable and Flexible Textile Electrodes for Biopotential Signal Monitoring: A review. Electronics 2019, 8, 479. [CrossRef]

105. Kannaian, T.; Neelaveni, R.; Thilagavathi, G. Design and development of embroidered textile electrodes for continuous measurement of electrocardiogram signals. J. Ind. Text. 2013, 42, 303-318. [CrossRef]

106. Alzaidi, A.; Zhang, L.; Bajwa, H. Smart textiles based wireless ECG system. In Proceedings of the 2012 IEEE Long Island Systems, Applications and Technology Conference (LISAT), Farmingdale, NY, USA, 4 May 2012; pp. 1-5. [CrossRef]

107. Smart Fabrics, a Technology That Revolutionizes Experiences-Ignasi Sayol. Available online: https://nemohealthcare.com/en/ (accessed on 13 June 2020).

108. Tang, D.H.; Gilligan, A.M.; Romero, K. Economic burden and disparities in healthcare resource use among adult patients with cardiac arrhythmia. Appl. Health Econ. Health Policy. 2014, 12, 59-71. [CrossRef]

109. Steinberg, C.; Bennett, M.T.; Krahn, A.D. Extended ECG Monitoring. In Cardiac Arrhythmias, Pacing and Sudden Death; Kowey, P., Piccini, J.P., Naccarelli, G., Eds.; Springer: Cham, Switzerland, 2017; pp. 48-59.

110. Priori, S.G. Survivors of out-of-hospital cardiac arrest with apparently normal heart. Need for definition and standardized clinical evaluation. Consensus Statement of the Joint Steering Committees of the Unexplained Cardiac Arrest Registry of Europe and of the Idiopathic Ventricular Fibrillation Registry of the United States. Circulation 1997, 95, 265-272.

111. Tomson, T.T.; Passman, R. Current and Emerging Uses of Insertable Cardiac Monitors: Evaluation of Syncope and Monitoring for Atrial Fibrillation. Cardiol. Rev. 2017, 25, 22-29. [CrossRef] [PubMed]

112. Steinberg, C.; Philippon, F.; Sanchez, M.; Fortier-Poisson, P.; O’Hara, G.; Molin, F.; Sarrazin, J.F.; Nault, I.; Blier, L.; Roy, K.; et al. A Novel Wearable Device for Continuous Ambulatory ECG Recording: Proof of Concept and Assessment of Signal Quality. Biosensors 2019, 9, 17. [CrossRef]

113. Zheng, J.; Zhang, Z.; Wu, T.; Zhang, Y. A wearable mobihealth care system supporting real-time diagnosis and alarm. Med. Biol. Eng. Comput. 2007, 45, 877-885. [CrossRef]

114. Cho, G.; Jeong, K.; Paik, M.J.; Kwun, Y.; Sung, M. Performance evaluation of textile-based electrodes and motion sensors for smart clothing. IEEE Sens. J. 2011, 11, 3183-3193. [CrossRef]

115. Pola, T.; Vanhala, J. Textile electrodes in ECG measurement. In Proceedings of the 2007 3rd International Conference on Intelligent Sensors, Sensor Networks and Information, Melbourne, QLD, Australia, 3-6 December 2007; pp. 635-639.

116. Paul, G.; Torah, R.; Beeby, S.; Tudor, J. The development of screen-printed conductive networks on textiles for biopotential monitoring applications. Sens. Actuator A Phys. 2014, 206, 35-41. [CrossRef]

117. Qin, H.; Li, J.; He, B.; Sun, J.; Li, L.; Qian, L. Novel Wearable Electrodes Based on Conductive Chitosan Fabrics and Their Application in Smart Garments. Materials 2018, 11, 370. [CrossRef] [PubMed] 